\title{
Market chain analysis of smallholder coffee producers in debub ari district of south omo zone, SNNPR, Ethiopia
}

\author{
Y. Alemayehu*iD \\ Received 13 July 2021, Revised 2 November 2021, Accepted 20 December 2021, Published online 31 December 2021
}

\section{A B S T R A C T}

This study mainly aimed at analyzing market chain analysis of coffee in the Debub Ari District. The descriptive and S-C-P model was used. Both primary and secondary data were collected from the study area. The multi-stage sampling technique employed for this study. A total of 194 coffee producer household heads have been randomly selected and interviewed with the help of pre-tested structured questionnaire. The focus group discussion and key informants interviews were conducted to supplement the formal data. The results of S-C-P model indicated that the four firms concentration ratio $\left(\mathrm{CR}_{4}\right)$ result in the study area was found to be tight oligopolistic for both red and dry coffee which accounts 89.2 and $80.0 \%$, respectively. About $72 \%$ of price setting was done by buyers, $27 \%$ negotiation and $1 \%$ by the producers. There are seven market channels, which have been identified in the study area. The computed marketing margin among different actors and channels indicated that the total gross marketing margin (TGMM) of coffee is high in channel I, II, III whereas the producers marketing margin (GMMp) was highest in channel VII. Therefore, the intervention is needed to improve coffee marketing chain through promoting cooperatives, infrastructural development and timely market information for efficient marketing system in the study area.

Keywords: Coffee market, Structure, Conduct, Performance, Southern Ethiopia

Southern Agricultural Research Institute, Jinka Agricultural Research Center, P.O. Box 096, Jinka, Ethiopia

*Corresponding author's email: yidnekachewalemayehu@yahoo.com (Y. Alemayehu)

Cite this article as: Alemayehu, Y. 2021. Market chain analysis of smallholder coffee producers in debub ari district of south omo zone, SNNPR, Ethiopia. Int. J. Agril. Res. Innov. Tech. 11(2): 61-68. https://doi.org/10.3329/ijarit.v11i2.57256

\section{Introduction}

Coffee is the major export crop in the Ethiopian economy (Petit, 2007). Coffee in today's time is one of the most valuable sources of export for the East African nations such as Ethiopia, Uganda, Kenya, and Tanzania. Coffee has accounted for an average of $60 \%$ of the total export earnings for the past five decades (Zekarias et al., 2012). Ethiopia is known to be the origin and the primary center of diversity of Coffeea arabica (Labouisse et al., 2008).

In the SNNPR, the total area covered by smallholder coffee producers is $217,080.29$ ha which gives the total production of $1,353,831.54$ Qt. (CSA, 2018). Accordingly, in Debub Ari District the total area covered by coffee production is 9341 ha. In the woreda, the total coffee produced annually is on average 44,525 Qt. About 4,986,766 kg of red coffee and 1,096885 kg of dry coffee were purchased from smallholder coffee producers in the woreda. Of the total about $1,040,950 \mathrm{~kg}$ of coffee have been marketed to the ECX (Debub Ari Woreda Agriculture Office, 2019).
Ethiopia is the leading $C$. arabica producer in Africa, ranking the fifth largest Arabica coffee producer and tenth in coffee export worldwide (ICO, 2014). Ethiopia is the leading C. arabica producer in Africa, ranking the fifth largest Arabica coffee producer and tenth in coffee export worldwide (ICO, 2014). Ethiopia is the leading $C$. arabica producer in Africa, ranking the fifth largest Arabica coffee producer and tenth in coffee export worldwide (ICO, 2014).

The long marketing chain for coffee marketing which made farmers to be discouraged on coffee market. Hence, the existing coffee marketing channel includes a number of intermediaries. The farmers wet and dried coffee cherries are sold to local collectors, small collectors in villages, and coming from town those who buy coffee from farmers and supply to larger collectors this reduce coffee price on the need of larger collector. Major exporters buy coffee from the central market, through auction. Such long market chain leads to unfair/ un proportional benefit farmers 
obtained from their coffee, which also plays its own role in affecting the quality of coffee through its effect on farmers' capacity to invest in processing facilities (Zinabu et al., 2017).

Although farmers in the study are prominent coffee producers, literature regarding market chain analysis of smallholder coffee producers in the study area even for the countries coffee producing zones is very limited. Therefore, this study has been conducted with the objectives of analyzing the market structure, conduct and performance, identify and map the marketing channels as well as actor's functions.

\section{Research Methodology}

\section{Data types and source}

Both qualitative and quantitative data types were collected from primary and secondary data sources.

\section{Sampling procedure}

For this particular study, Debub Ari District was selected purposively based on the coffee production potential and marketing practice. The study has been employed multi-stage sampling techniques to draw sample of household heads. Accordingly, from 48 kebeles in the Woreda in the first stage 30 potential kebeles in coffee production and marketing was selected purposely for this study based on woreda information. In the second stage, out of 30 potential Kebeles 5 Kebeles was randomly selected. These selected kebeles were Shepi, Gedir, Shesher, Metser and Shamamer. In the third stage, the number of sample households from each sample Kebeles was determined from the recent lists of households using proportional to size. Therefore, given the relative homogeneity of households in terms of their socio- economic characteristics and livelihood style sample households was drawn using simple random sampling method from each kebele.

\section{Sample size determination}

To determine the appropriate sample size, the basic factors to be considered were the level of precision required by users, the confidence level desired and degree of variability. Thus, it was determined using a simplified formula provided by (Kothari, 2004).

$\mathrm{n}=\frac{z^{2} p q N}{e^{2}(N-1)+z^{2} p q}$

Where, $n$ : is the sample size for a finite population, $\mathrm{N}$ : size of population which is the number of coffee producers households in the Woreda, p: population reliability (or frequency estimated for a sample of size $n$ ), where $p$ is 0.5 which is taken for all developing countries population and $p+q=1$, e: margin of error considered was $7 \%$ for this study because of budget constraint to collect large sample with margin of error $5 \%$. $\mathrm{Z} \mathrm{a} \mathrm{/2:} \mathrm{normal} \mathrm{reduced}$ variable at 0.05 level of significance $z$ is 1.96 . The sampling unit here was households and sampling frame was all the 5 kebeles coffee producers household lists which has been available in the kebele. Accordingly, sample size was determined as follows:

$$
\begin{aligned}
& \mathrm{N}=18,426 \text { Hhds } \\
& \mathrm{n}=\frac{(1.96 \times 1.96) \times(0.5 \times 0.5) \times(18,426)}{(0.07 \times 0.07) \times 18,426+(1.96 \times 1.96) \times(0.15 \times 0.85)}=194
\end{aligned}
$$

\section{Methods of data collection}

Formal and informal methods of data collection tools were implemented to acquire primary data. Among the informal data collection tools key informant interview and focus group discussion with pre-defined social groups (elders, model farmers, women's, DAs and experts) were conducted before formal survey to collect general information about the study area, coffee production and marketing. A checklist was also used to guide the informal discussion conducted to generate data that cannot be collected from individual interviews. Formal data collection was employed with the help of pre- tested structured questionnaire. In this study, both secondary and primary data were used from different sources. Primary data was collected from a total of 194 coffee producer sample households, 4 wholesalers, 5 processors, 3 retailers, 2 brokers, 3 collectors about their buying and selling strategies, source of market information, demographic characteristics and other relevant information.

\section{Method of data analysis}

Descriptive analysis was employed for estimating cost, margins and profits along coffee market chain. Statistics such as average, weighted average, frequencies, and percentages were computed. Structure, conductperformance descriptive model has been employed to study the marketing conduct structure, and performance of the coffee marketing system. Conduct would decline and there would be a consequent decrease in output and allocative efficiency (Scott, 1995). 


\section{Market concentration measure}

According to Kohls and Uhl (1985), as a rule of thumb, four largest enterprises' concentration ratio of $50 \%$ or more (an indication of a strongly oligopolistic industry), 33-50\% (a weak oligopoly) and less than that (competitive industry) which was used to evaluate in what manner the coffee market was structured. The greater the degree of concentration, the greater the possibility of noncompetitive behavior, such as collusion, exists in the market.

$\mathrm{C}=\sum_{i=1}^{i=r} \mathrm{Si}, i=1,2,3 \ldots, r$,

Where,

$\mathrm{C}=$ Concentration ratio

$\mathrm{S}_{\mathrm{i}}=$ Market share in percentage of $\mathrm{i}^{\text {th }}$ traders

$\mathrm{r}=$ The number of largest traders which participate in the market for which the ratio is going to be calculated.

$\mathrm{S}_{\mathrm{i}}=\frac{V i}{\Sigma V i}$

Where,

$\mathrm{V}_{\mathrm{i}}=$ Amount of product handled by the buyer,

$\mathrm{MS}_{\mathrm{i}}=$ Market share of buyer $\mathrm{i}$

$\sum \mathrm{V}_{\mathrm{i}}=$ Total amount of product handled by the $\mathrm{r}$ firms.

The marketing conduct was analyzed in terms of the price fixing mechanisms, price information transmittal, competitive behavior, practices or strategies of maximizing profits, existence of formal and informal marketing groups, illegal practices prevailing, and the alternative market outlets in the market with respective to smallholder farmers. Market performance was assessed using gross and profit margin analysis.

The computation used to obtain the total gross marketing margin was as follows:

TGMM $=\frac{\text { Consumer price }- \text { producers price }}{\text { Consumer price }} \times 100$

Where,

TGMM $=$ Total gross marketing margin

It is useful to introduce the idea of 'farmer's portion', or 'producer's gross margin' (GMMp) which is the portion of the price paid by the consumer that goes to the producer. The producer's margin was calculated as:

$\mathrm{GMMp}=\frac{\text { Price paid by consumer-Marketing gross margin }}{\text { Price paid by consumers }} \times 100(5)$

Where,

GMMp $=$ Gross marketing margin of producers The net marketing margin (NMM) was the percentage over the final price earned by the intermediary as net income once marketing costs were deducted.

$\mathrm{NMM}=\frac{\text { Gross margin }- \text { Marketing cost }}{\text { Price paid by consumers }} \times 100$

Where,

NMM = Net marketing margin

Results and Discussion

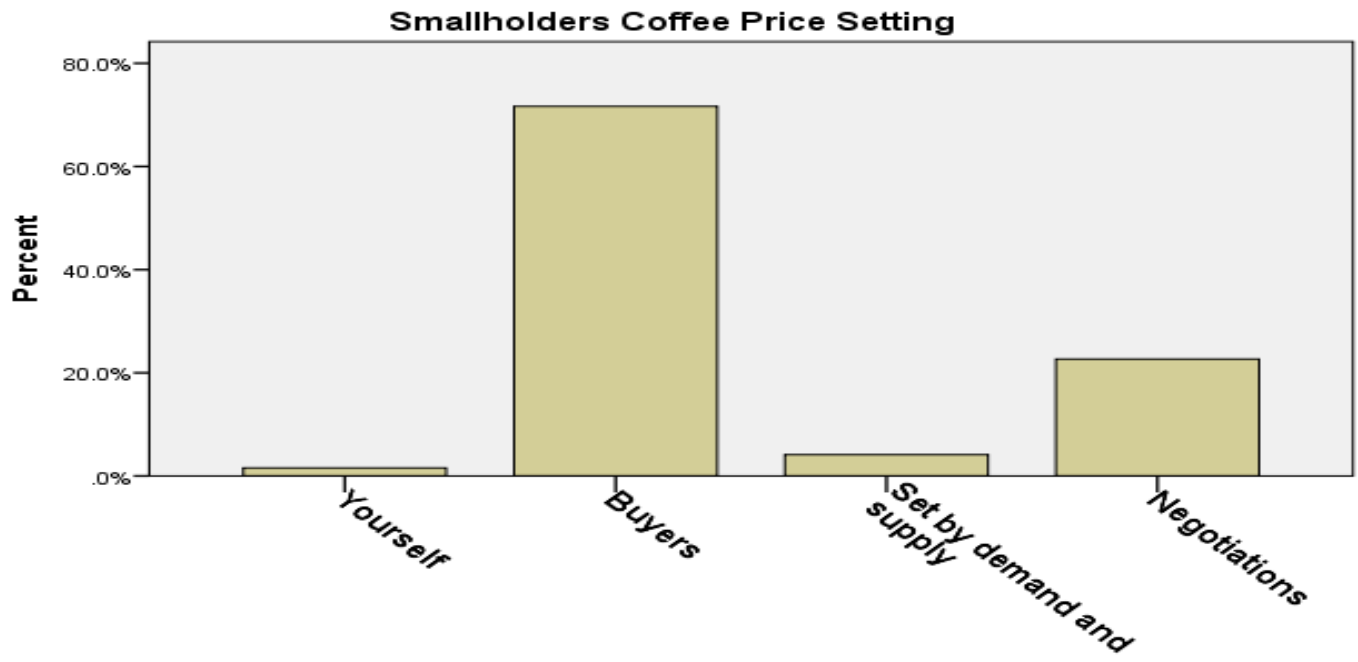

Fig. 1. Smallholder coffee producer price setting.

As shown in the Fig. 1 with regard to coffee price setting for coffee in the study area majority $72 \%$ of the price for coffee has been fixed by buyers, $4 \%$ was by the demand and supply of the market, $2 \%$ was by the smallholder coffee producers whereas $22 \%$ of the sample respondents those who said by negotiation. This result indicates that smallholder coffee producers were price takers, which made them to get low benefit from their coffee. 


\section{Market structure, conduct and performance}

\section{Market structure}

\section{The degree of market concentration}

Table 1. Market concentration ratio for red coffee in Debub Ari Woreda.

\begin{tabular}{|llllll|}
\hline $\begin{array}{l}\text { No. of } \\
\text { traders }\end{array}$ & $\begin{array}{l}\text { Cumulative } \\
\text { of traders }\end{array}$ & $\begin{array}{l}\text { \% of cumulative } \\
\text { traders }\end{array}$ & $\begin{array}{l}\text { Quantity } \\
\text { purchased in } \\
\text { (Qtls) }\end{array}$ & $\begin{array}{l}\text { \% share of } \\
\text { purchase }\end{array}$ & \% Cumulative \\
\hline 1 & 1 & 14.29 & $22,871.43$ & 49.3 & 49.9 \\
\hline 1 & 2 & 28.58 & 9271.88 & 19.9 & 69.8 \\
\hline 1 & 3 & 42.87 & 5173.77 & 11.2 & 81.0 \\
\hline 1 & 4 & 57.16 & 4077.58 & 8.8 & 89.8 \\
\hline 1 & 5 & 71.45 & 2724.55 & 5.9 & 95.7 \\
\hline 1 & 6 & 85.74 & 1599.63 & 3.4 & 99.1 \\
\hline 1 & 7 & 100.00 & 665.42 & 1.4 & 100.0 \\
\hline & & & $46,384.26$ & 100 & \\
\hline
\end{tabular}

Source : Survey Result, 2019 (Red coffee= Fresh coffee harvested from coffee tree)

Table 2 . Market concentration ratio for dry coffee in Debub Ari Woreda.

\begin{tabular}{|llllll|}
$\begin{array}{l}\text { No. of } \\
\text { traders }\end{array}$ & $\begin{array}{l}\text { Cumulative } \\
\text { of traders }\end{array}$ & $\begin{array}{l}\text { \% of cumulative } \\
\text { traders }\end{array}$ & $\begin{array}{l}\text { Quantity } \\
\text { purchased } \\
\text { in (Qtls) }\end{array}$ & $\begin{array}{l}\text { \% share of } \\
\text { purchase }\end{array}$ & \% Cumulative \\
\hline 1 & 1 & 6.6 & 5386.44 & 50.90 & 50.9 \\
\hline 1 & 2 & 13.3 & 1433.55 & 13.60 & 64.5 \\
\hline 1 & 3 & 20.0 & 918.30 & 8.70 & 73.2 \\
\hline 1 & 4 & 26.6 & 714.32 & 6.80 & 80.0 \\
\hline 1 & 5 & 33.3 & 623.33 & 5.90 & 85.9 \\
\hline 1 & 6 & 40.0 & 433.56 & 4.10 & 90.0 \\
\hline 1 & 7 & 46.7 & 260.00 & 2.50 & 92.5 \\
\hline 2 & 9 & 60.0 & 220.00 & 2.10 & 94.6 \\
\hline 1 & 10 & 66.7 & 154.00 & 1.50 & 96.1 \\
\hline 1 & 11 & 73.3 & 149.50 & 1.40 & 97.5 \\
\hline 1 & 12 & 80.0 & 110.00 & 1.04 & 98.5 \\
\hline 1 & 13 & 86.7 & 90.00 & 0.85 & 100.0 \\
\hline 2 & 15 & 100.0 & 82.50 & 0.78 & \\
\hline & & & $10,575 \cdot 50$ & & 99.4 \\
\hline
\end{tabular}

Source: Own Survey, 2019 (Dry Coffee= which is dried before pulping coffee)

As we have seen in the above two tables the four top traders have been taken from the study area and concentration ratio $\left(\mathrm{CR}_{4}\right)$ was calculated. Accordingly, the market concentration ratio for the red as well as dry coffee in the study area were found to be $89.2 \%$ and $80.0 \%$, respectively which indicates that there is strong or tight oligopoly that has been observed with regard to the coffee marketing in the study area. This indicates that there is imperfect and inefficient coffee marketing system in the study area, which made the farmers to get un-proportional benefit from their coffee during coffee marketing. This result therefore calls the intervention, which is needed in order to adjust the inefficient coffee marketing system in the study area.

\section{Coffee marketing actors and their functions}

According to survey result, six coffee marketing actors have been identified in the study area. These were producers, collectors, wholesalers, retailers, processors and consumers, which were the main actors on the coffee marketing. The role of each actor on coffee production and marketing, their interaction among different actors as well as the flow of coffee through each market channels were indicated in Table 3 .

Collectors: These are an actors that collect a large volume of coffee at the farm gate from the smallholder coffee producer and provide to the wholesaler and processor in the study area. The total amount of coffee purchased from smallholder coffee producer through collectors are amounted to be 177.58 Qtls. The main market outlets for the collectors are wholesaler and processor. 
Wholesaler: Wholesalers are traders that collect a large volume of coffee from collectors and mainly sell to exporters through ECX. According to sample survey result the total amount of coffee purchased by wholesaler from the sample smallholder coffee producer was about 292.27 Qtls. They play significant role in the market chain who mainly known for purchase of bulky products with better financial and information capacity as well as reside in the town. They are major actors in the channel and they purchase coffee either directly from farmer or mainly through collectors.

Retailers: Retailers are known for their limited purchasing with low financial and information capacity. They are the main actors along the channel and deliver coffee to the consumer in small amount. The amount of coffee purchased through these actors was estimated to be 113.99 Qtls from smallholder coffee producer in the study area.

Processor: These are the market actors with their main motive of creating large profit through value addition on the product. These actors purchase large volume of coffee from smallholder as well as collectors and market it to the exporters through ECX. The total amount purchased by this actor in the study area was 303.16 Qtls.

Consumers: Consumers are the final purchasers of coffee mostly from retailers for consumption purpose and it is the last link along the channel. The total amount of coffee sold to this market actor was estimated to be 13 Qtls, which is provided from the smallholder coffee producers.

Exporters: These marketing actors purchase coffee from different coffee traders within all around the country and provide to the international market in order to get more benefit from the business. ECX plays a significant role in market facilitation, which is a government established exchange market that brings the customers such as wholesaler, processor and exporters together for undertaking effective marketing of coffee and other export commodity. According to the secondary information obtained from the district, about 6615.57 Qtls washed and 3793.93 Qtls unwashed, the traders have marketed coffees to ECX for export from the district.
According to the secondary information obtained from the ECX, the coffee from South Omo Zone was categorized under the E- type, which lies between grade 5 and 8 due to poor quality of coffee supplied by the farmers.

\section{Marketing conduct}

Price setting and purchase strategy: Price setting mechanism and purchasing strategy has been practiced by the traders, which enables us to understand the behavior of the market. The survey result indicates that the price for the coffee has been mainly fixed by the traders. Due to strong oligopolistic nature the smallholder coffee producers have poor bargaining power in the study area due to absence of other market alternatives and existence of very limited traders available in the study area. However, the traders revealed that they have been used better scaling and give better price for those who can able to provide quality coffee.

\section{Market performance of coffee}

\section{Market margin}

The computed marketing margin among different actors and channels indicated that the total gross marketing margin (TGMM) of coffee is high in channel I, II, III, which are $52.4 \%$ for each and followed by channel IV and V, which account 49.87 of consumer's price. However, the producers' price in consumers' price or the producers' gross marketing margin (GMMp) was highest in channel VI and VII and followed by channel IV and V. As you can see in the Table 3 the proportion of marketing margin in both channels IV and V higher than the gross margin received by the actors along the channels due to reduction in the numbers of intermediary along the channel. However, in the channel I, II, III the gross marketing margin of producers was lower that indicates that as the number of intermediary increase the producers share become lower. Therefore, the number of intermediary involved along the channel has to be reduced in order to maximize the benefits of smallholder coffee producers in the study area. The result also indicates that the maximum gross marketing margin from traders was received by the exporters, which accounts $29.8 \%$ followed by retailers $18.8 \%$ in channel VI. The minimum gross margin was received by collectors, which accounts $5.01 \%$ in channel I, II and III. 
Table 3. Red coffee cherry marketing margin and profit along all the channels.

\begin{tabular}{|c|c|c|c|c|c|c|c|c|}
\hline \multicolumn{4}{|c|}{ Actors } & \multicolumn{5}{|c|}{ Coffee Market Channels } \\
\hline & & I & II & III & IV & $\mathrm{V}$ & VI & VII \\
\hline - & Selling price & 38.00 & 38.00 & 38.00 & 40.00 & 43.00 & 45.00 & 60.00 \\
\hline- & Harvesting \&marketing cost (birr/kg) & 9.80 & 9.80 & 9.80 & 9.80 & 9.80 & $15 \cdot 70$ & $15 \cdot 70$ \\
\hline- & GMMp (\%) & 47.60 & 47.60 & 47.60 & 50.13 & 53.80 & 75.00 & 100.00 \\
\hline - & NMM/Profit (birr/kg) & 28.20 & 28.20 & 28.20 & 30.20 & 30.20 & 29.30 & $44 \cdot 30$ \\
\hline- & Profit share (\%) & 41.80 & 41.80 & 51.00 & 51.90 & 52.80 & 71.30 & 100.00 \\
\hline \multicolumn{9}{|c|}{ Collectors } \\
\hline - & Purchase price (birr/kg) & 38.00 & 38.00 & 38.00 & & & & \\
\hline - & Selling price (birr $/ \mathrm{kg}$ ) & 42.00 & 42.00 & 42.00 & & & & \\
\hline- & Marketing cost (birr/kg) & 2.94 & 2.94 & 2.94 & & & & \\
\hline - & GMMcol (\%) & 5.01 & 5.01 & 5.01 & & & & \\
\hline- & NMM/Profit (birr/kg) & 1.06 & 1.06 & 1.06 & & & & \\
\hline - & Profit share (\%) & 1.60 & 1.60 & 1.90 & & & & \\
\hline \multicolumn{9}{|c|}{ Wholesalers } \\
\hline - & Purchase price (birr/kg) & 42.00 & 42.00 & 42.00 & 40.00 & & & \\
\hline- & Selling price (birr $/ \mathrm{kg}$ ) & 56.00 & 56.00 & 56.00 & 56.00 & & & \\
\hline- & Marketing cost (birr/kg) & 2.80 & 2.80 & 2.80 & 2.80 & & & \\
\hline- & GMMw (\%) & 17.50 & $17 \cdot 50$ & $17 \cdot 50$ & 20.10 & & & \\
\hline - & NMM/Profit (birr/kg) & 11.20 & 11.20 & 11.20 & 13.20 & & & \\
\hline- & Profit share (\%) & 16.60 & 16.60 & 20.30 & 22.70 & & & \\
\hline \multicolumn{9}{|c|}{ Retailers } \\
\hline- & Purchase price (birr/kg) & & & & & & 45.00 & \\
\hline- & Selling price (birr/kg) & & & & & & 60.00 & \\
\hline- & Marketing cost (birr/kg) & & & & & & 3.20 & \\
\hline- & GMMrt (\%) & & & & & & 25.00 & \\
\hline- & NMM/Profit (birr/kg) & & & & & & 11.80 & \\
\hline- & Profit share (\%) & & & & & & 28.70 & \\
\hline \multicolumn{9}{|c|}{ Processors } \\
\hline- & Purchase price (birr/kg) & 43.00 & 43.00 & & & 43.00 & & \\
\hline- & Selling price (birr/kg) & 56.00 & 56.00 & & & 56.00 & & \\
\hline- & Marketing cost (birr/kg) & 1.80 & 1.80 & & & 1.80 & & \\
\hline- & GMMpr (\%) & 16.30 & 16.30 & & & 16.30 & & \\
\hline- & NMM/Profit (birr/kg) & 12.20 & 12.20 & & & 12.20 & & \\
\hline- & Profit share (\%) & 18.10 & 18.10 & & & 21.30 & & \\
\hline \multicolumn{9}{|c|}{ Consumer } \\
\hline- & Purchase price & & & & & & 60.00 & 55.00 \\
\hline \multicolumn{9}{|c|}{ Exporter } \\
\hline- & Purchase price (birr/kg) & 56.00 & 56.00 & 56.00 & 56.00 & 56.00 & & \\
\hline- & Selling price (birr/kg) & 79.80 & 79.80 & 79.80 & 79.80 & 79.80 & & \\
\hline- & Marketing cost (birr/kg) & 9.00 & 9.00 & 9.00 & 9.00 & 9.00 & & \\
\hline- & GMMex (\%) & 29.80 & 29.80 & 29.80 & 29.80 & 29.80 & & \\
\hline- & NMM/Profit (birr/kg) & 14.80 & 14.80 & 14.80 & 14.80 & 14.80 & & \\
\hline - & Profit share (\%) & 21.90 & 21.90 & 26.80 & 25.40 & 25.90 & & \\
\hline- & TGMM (\%) & 52.40 & 52.40 & 52.40 & 49.87 & 49.87 & 25.00 & 00.00 \\
\hline- & Total profit (birr/kg) & 67.50 & 67.50 & $55 \cdot 30$ & 58.20 & 57.20 & 41.10 & $44 \cdot 30$ \\
\hline- & Mean profit in each channel (birr/kg) & 13.50 & 13.50 & 13.80 & 19.40 & 19.10 & 20.55 & $44 \cdot 30$ \\
\hline
\end{tabular}

Source: Own computation from survey result, 2019.

As depicted on the above table 3 , the total profit is highest in the channel I and II followed by channel IV. The exporters have the highest profit from among other traders, which accounted for birr $14.8 / \mathrm{kg}$. In the channels VII, the producers have highest profit, which accounted 44.3 birr this was because of producers directly sold to consumers or absence of intermediary. Hence, the benefit for the smallholder coffee producers increases as the number of intermediary decreases.

\section{Summary and Conclusions}

The results of S-C-P model indicated that the four firms concentration ratio $\left(\mathrm{CR}_{4}\right)$ result in the study area, which indicated tight oligopolistic nature for both red and dry coffee, which accounts 89.2 and $80.0 \%$, respectively. This indicates that there is imperfect and inefficient coffee marketing system in the study area, which made the farmers to get un proportional benefit from their coffee during coffee marketing. This result therefore calls the intervention, which is needed in order to adjust the inefficient coffee marketing system in the study area. 
The major market actors that are involved in coffee marketing in the study area include producers, collectors, wholesalers, retailers and consumers. In the channel I, II, III the gross marketing margin of producers was lower that indicates that as the number of intermediary increase the producers share become lower. Therefore, the number of intermediary involved along the channel has to be reduced in order to maximize the benefits of smallholder coffee producers in the study area.

The performance and efficiency analysis based on the gross margin and profit margin. The computed marketing margin among different actors and channels indicated that the total gross marketing margin (TGMM) of coffee is high in channel I, II, III which are $52.4 \%$ for each followed by channel IV and V, which account 49.87 of consumer's price. However, the producers' price in consumers' price or the producers' gross marketing margin (GMMp) was highest in channel VI and VII as compared to channel IV and V. The proportion of marketing margin in both channels IV and V higher than the gross margin received by the actors along the channels. This is due to reduction in the numbers of intermediary along the channel. However, in the channel I, II, III the gross marketing margin of producers was lower that indicates that as the number of intermediary increase the producers share become lower. Therefore, the number of intermediary involved along the channel has to be reduced in order to maximize the benefits of smallholder coffee producers in the study area. The result also indicates that the maximum gross marketing margin from traders was taken by the exporters, which accounts $29.8 \%$ followed by retailers $18.8 \%$ in channel VI. The minimum gross margin was taken by collectors, which accounts $5.01 \%$ in channel I, II and III. This might be due to low financial capacity of the collectors to purchase large volume of coffee from smallholder coffee producers.

With regard to market conduct majority $72 \%$ of the respondents revealed that the price setting was by buyers whereas $27 \%$ was by negotiation and only $1 \%$ was by farmers, which indicates the majority of the sample respondents have been price takers.

The sample households sold different proportion of their coffee to different market outlets in the district, which include collectors, wholesalers, retailers, processors and consumers. Result of the survey revealed that about $68.0 \%$ of households sold their coffee to collectors whereas $66.5 \%$, $36.6 \%, 72.5 \%$ and $15 \%$ of the sample households sold their coffee to wholesalers, retailers, processors and consumers, respectively. The majority of sample respondents have been sold to the processors market outlets while less amount of coffee was sold to consumers.

\section{Recommendations}

From the findings of this study the following relevant recommendations have been drawn in order to help in designing appropriate intervention strategies to improve the market chain for coffee marketing to enhance the benefits of smallholder coffee producers in the study area.

- The market information is very crucial component in marketing system for a given commodity. The smallholder coffee producers have been getting the informal market information from relatives, neighbor, traders as well as visiting the market. Access to market information was found to be significantly influence the smallholder coffee producers in choosing better market outlet. It enables the smallholder coffee producers in analyzing the price difference on the farm gate and consumer market outlets that increases the probability to choose the consumers outlet market which gives better price. This indicates that as the smallholder coffee producers are more accessible to the market information they more likely to sell to the better market outlet than other outlets in the study area. Therefore, the provision of adequate, timely, reliable and formal market information from concerned body is essential to enhance coffee producers' benefit and bargaining power through avoiding information asymmetry.

- Promoting the cooperative is very essential to enhance the agricultural product marketing in general and coffee marketing in particular. It plays a great role in the coffee marketing and able to lower the transaction costs in order to increases the benefits of the farmers. Being a member of cooperative was significantly influenced in searching for better market for their coffee that can able to maximize coffee producers' benefit in the study area. However, although there was multipurpose cooperative in the study area it has been functioning on the sugar and oil distribution for its member rather than coffee marketing. Therefore, the development and promotion of coffee marketing cooperative is needed in the study area in order to increase the incomes of smallholder coffee producers through purchasing at reasonable price and paying the dividend for its members.

- The development of infrastructure and market accessibility is critical for the smallholder coffee producers that enables them to choose the better alternative market outlets. The adequate infrastructural development and market accessibility is 
important that can able to enhance the benefits of smallholder coffee producers in the study area. Therefore, adequate infrastructural development and market accessibility with good facility is needed to enable the smallholder coffee producers in choosing the better market outlets to increase the benefit.

\section{Author contribution}

This research has been mainly conducted by me and no other authors involved.

\section{Acknowledgements}

I would like to thank my sincere gratitude to the South Agricultural Research Institute (SARI ) as well as Jinka Agricultural Research Center for providing me the opportunity to learn my MSc degree and funding the study.

\section{Competing interests}

The authors declare that they have no competing interests.

\section{Ethical approval}

Not applicable.

\section{References}

CSA (Central Statistics Agency of Ethiopia). 2018. Report on area and crop production of major crops for 2016/2017 Meher Season, Addis Abeba, Ethioipia.

Debub Ari Woreda Agriculture and Natural Resource Office. 2019. Annual report on
Coffee. Debub Ari, Gather, Ethiopia.

ICO (International Coffee Organization). 2014. World coffee trade (1963-2013): A review of markets, challenges and opportunities facing the sector. ICC $112^{\text {th }}$ session, 3-7 March 2014, London, United Kingdom. 29p.

Kohls, R.L. and Uhl, J.N. 1985. Marketing of Agricultural Product. $6^{\text {th }}$ Edition. McMillian Publishing Company, New York, USA. 624p.

Kothari, C.R. 2004. Research Methodology. Methods and Techniques ( $2^{\text {nd }}$ edn). New Age International: New Delhi, India. 401p.

Labouisse, J.P., Bayetta, B., Surendra, K. and Benoit, B. 2008. Current status of coffee (Coffea arabica L.) genetic resources in Ethiopia: Implications for conservation. Gene. Res. Crop Evol. 5: 5079. https://doi.org/10.1007/s10722-008-9361-7

Petit, N. 2007. Ethiopia's coffee sector: A bitter or better Future. J. Agrarian Change. 7(2): 225-263.

Scott, G.J. 1995. Prices, products and people: Analyzing agricultural markets in developing countries. Lynne Reinner publishers, Boulder, London. 498p.

Zekarias, S., Kaba, U. and Zerihun, K. 2012. Analysis of market chains of forest coffee in southwest Ethiopia. Acad. J. Plant Sci. 5(2): 28-39.

https://doi.org/10.5829/idosi.ajps.2012.5.2.2748

Zinabu, W., Adimasu, T., Selemawit, Y., Tigistu, G. and Tegegn, T. 2017. A review on coffee farming, production potential and constraints in Gedeo Zone, Southern Ethiopia. J. Nat. Sci. Res. 7(23): 1-9. 